\title{
The rhetoric of hope: integrating rhetorical practice into the pedagogy of Paulo Freire
}

\begin{abstract}
Reading Paulo Freire's Pedagogy of the oppressed, one might easily conclude that rhetoric has no place in a classroom so thoroughly imbued with the ethics of dialogue. However, this essay suggests that rhetoric plays a productive and in fact necessary role in Freire's pedagogy of the oppressed. Drawing from the sophistical techniques of imitatio and dissoilogoi, I suggest that true liberation from a dominated consciousness goes through rather than around the methods of rhetorical persuasion, methods that not only develop rhetorical skills in students but that also encourage rhetorical performance on the part of the educators. Dialogue remains central to this pedagogy but becomes enriched by its natural counterpart, rhetoric, so that the aim is not only cognitive liberation but the accrual of practical power.
\end{abstract}

Keywords: Paulo Freire. Rhetoric. Sophistical education.

\section{A retórica da esperança: integrando a retórica prática na pedagogia de Paulo Freire}

Resumo: Ao ler Pedagogia do oprimido de Paulo Freire, pode-se concluir facilmente que não há lugar para a retórica em uma sala de aula tão completamente imbuída pela ética do diálogo. No entanto, este ensaio sugere que a retórica desempenha um papel produtivo e de fato necessário na pedagogia do oprimido de Freire. Com base nas técnicas sofísticas do imitatio e do dissoilogoi, sugiro que a verdadeira libertação de uma consciência dominada seja por meio de - e não contornando - os métodos da persuasão retórica, métodos que não apenas desenvolvem habilidades retóricas nos estudantes, mas que encorajam a performance

* Ph.D. in Communication, University of Pittsburgh, USA. Associate Professor at the Department of Communication, Texas A\&M University, USA. E-mail: crick@tamu.edu 
retórica dos educadores. O diálogo permanece central nessa pedagogia, mas se torna enriquecido por sua contraparte natural, a retórica, de modo que seu objetivo não seja somente a libertação cognitiva, mas o acréscimo de poder prático.

Palavras-chave: Paulo Freire, Retórica, Educação sofística.

\section{La retórica de la esperanza: la integración de la retórica práctica en la pedagogía de Paulo Freire}

Resumen: La lectura de la Pedagogía del oprimido de Paulo Freire, se puede fácilmente concluir que no hay lugar para la retórica en un aula imbuida por la ética del diálogo. Sin embargo, este ensayo sugiere que la retórica juega un papel productivo y de hecho es necesario en la Pedagogía del oprimido de Freire. Basado en las técnicas sofísticas del imitatio y del dissoilogoi, yo sugiero que la verdadera libertad de una consciencia dominada que sea través de - y no contorneando - los métodos de la persuasión retórica, métodos que no solamente desarrollan habilidades retóricas en los estudiantes, sino que fomentan una performance retórica de los educadores. El diálogo permanece central en esta Pedagogía, pero se enriquece por su contraparte natural, la retórica, haciendo de su objetivo no solo la libertad cognitiva, pero también el aumento del poder práctico.

Palabras clave: Paulo Freire. Retórica. Educación sofística.

\section{Introduction}

One rarely encounters a favorable word about rhetoric in the writings of Paulo Freire. At best, he uses rhetoric to refer to a way of speaking about the subject matter of teaching, as when he urges integrating a concern for material conditions “in our 'rhetoric' about education” (FREIRE, 1998a, p. 48). But most of the time, Freire sees rhetoric through Platonic eyes as a combination of manipulative and empty speech. For example, he considers the poverty of neoliberal political culture and asks "how can I vote for a politician whose rhetoric is an affront to solidarity and an 
apology for racism?” (FREIRE, 1998a, p. 75). He finds positive trends in the movement away from ideological discourse precisely because of its increasing intolerance for what he calls "verbal incontinence - discourse that loses itself in a tiresome rhetoric bereft of so much as some sonority and rhythm” (FREIRE, 1998b, p. 84). He condemns the cowardice of educators who refuse "to run the risk of adventuring into dialogue" and choose instead to "retreat into their discursive and rhetorical classes, which have a lulling effect on students" (FREIRE, 1974, p. 110). In other words, rhetoric in Freire represents the opposite of dialogue - which is monologic persuasion - a concept in his work which is associated with sloganeering, extension, manipulation, propaganda, and domestication.

Given these connotations, it is therefore all the more surprising - and telling - that Freire relates a story in his last, reflective work, Pedagogy of hope, that celebrates what are unmistakably classical rhetorical virtues. His narration recounts an experience he had while still a young scholar in his twenties working for the Brazilian Industrial Social Service (SESI). At the time, he recalls, he had become "accustomed to give long talks on the subjects that had been selected... repeating the traditional route of discourse about something that you would give an audience” (FREIRE, 1998b, p.16). On this particular occasion, his general topic was authority, freedom, punishment, and reward in education, and his specific intent was to critique the prevalence of corporal punishment by peasants in the Brazilian Northeast and to argue "for a dialogical, loving relationship between parents and children in place of violent punishments" (FREIRE, 1998b, p. 17). But then something unexpected happened: "a man of about forty, still rather young but already worn out and exhausted, raised his hand and gave me the clearest and most bruising lesson I have ever experienced in my life as an educator". The man confronted Freire's privileged position as a representative of the middle class, unfamiliar with the experience of living in pitiful, cramped houses, working to physical exhaustion, and being prohibited from being happy or even having hope. Freire recounted the man's speech and the words of his conclusion: 
It's one thing to come home, even tired, and find the kids all bathed, dressed up, clean, well fed, not hungry - and another thing to come home and find your kids dirty, hungry, crying, and making noise. And people have to get up at four in the morning the next day and start all over again - hurting, sad, hopeless. If people hit their kids, and even "go beyond bounds", as you say, it's not because people don't love their kids. No, it's because life is so hard they don't have much choice (FREIRE, 1998b, p. 19).

Freire reflected that "I still see him standing in one of the aisles of that big auditorium of so long ago, head erect, eyes blazing, speaking in a loud, clear voice, sure of himself, speaking his lucid speech" (FREIRE, 1998b, p. 18). In short, the revelatory effect of the man's speech on Freire was due to his harnessing of the power of rhetoric:

In his intonations, his laborer's syntax and rhythm, the movements of his body, his hands of an orator, in the metaphor so common to popular discourse, called attention of the educator in front of him, seated, silent, sinking down into his chair, to the need, when speaking to the people, for the educator to be up to an understanding of the world people have (FREIRE, 1998b, p. 19).

Not only, then, did he affect Freire because of his oratorical skill, but he taught Freire the centrality of a foundational rhetorical principle - know your audience.

This lesson, of course, comes straight from Plato, with whom Freire shares so much affinity. As Stephen Brown (2011) writes, his "radical praxis is rooted in an ancient rhetorical tradition, and in the radical critique of power of Plato's Socrates in particular, of which Paulo Freire's radical praxis is a genealogical descendent, operating across 2.500 years of critical inquiry”. On the one hand, Freire echoes the suspicion of rhetoric Plato expressed in his Gorgias insofar as he sees rhetoric so often used as an instrument of injustice, a tool like the modern-day Polus or Callicles who wish to manipulate the masses through coercion 
and flattery to follow the will of the powerful. On the other hand, Freire clearly sees a role for rhetoric when it is harnessed to an idealistic aim and emancipatory ethic that follows on the heels of dialogical (or in Plato's language, dialectical) inquiry into the nature of the soul. In his Phaedrus, Plato tasks the noble rhetorician with the responsibility to be able to first "describe the soul with absolute precision and enable us to understand what it is" before then being able to "coordinate each kind of soul with the kind of speech appropriate to it” (FREIRE, 1998b, p. 271). In his reading of the Phaedrus, Richard Weaver (1985, p. 25) summarizes Plato's view of noble rhetoric this way: "rhetoric at its truest seeks to perfect men by showing them better versions of themselves, links in that chain extending up toward the ideal, which only intellect can apprehend and only the soul have affection for". To pursue this type of rhetoric, therefore, requires knowledge of the world, understanding of the souls of others, and the ability to express oneself in a way that moves those souls toward an actual possibility.

What I wish to argue is that Freire's pedagogy is, in fact, incomplete without an explicit recognition of the rhetorical commitments it entails - and not only with respect to the tradition of Plato, but also with the more democratic tradition of the Sophists, as we shall see. And this is more than arguing that rhetoric can supplement his method. It is claiming that rhetoric is already present in his philosophy, but often concealed because of his tendency to rely on the kind of stark dualisms between monologue and dialogue, between persuasion and communication, that often appear in his works as a means both of critiquing "banking” models of education and highlighting the emancipatory quality of his own pedagogy. However, rhetoric is clearly necessary for the success of his vision. First, from a Platonic perspective, rhetorical proficiency on the part of the teacher is in fact a necessary component not only for producing moments of “conscientization”, or critical consciousness, but also in communicating knowledge to students in a language that is meaningful to their own life experience - a lesson Freire learned in his encounter 
with the orator during his lecture on corporal punishment. Second, from a sophistical perspective, for students to become empowered requires them to master rhetorical skills themselves so that they can translate their critical consciousness into a language that expresses that power - just as the orator did to Freire. I believe all that only by recognizing these rhetorical components to Freire can his pedagogy be adapted to the educational context of the highly mediated and globalized environment of the $21^{\text {st }}$ century.

\section{Freire'sconception of rhetoric as anti-dialogue}

As with all of Freire's concepts, his critique of rhetoric and his praise of dialogue must be seen as a natural outgrowth of his early experience of adult literacy education with Brazilian and Chilean agricultural laborers during the 1960s. First, it is important for readers from more developed countries to understand that when Freire (2000, p. 174) speaks of the "oppressed", he refers specifically to the class of "Latin-American peasants, whose world usually ends at the boundaries of the latifundium, whose gestures to some extent stimulate those of animals and the trees, and who often consider themselves equal to the latter". Unlike what he calls the "urban oppressed," who "live in an expanding context in which the oppressive command center is plural and complex", the rural oppressed live under the control of a dominant figure and spend their lives largely cultivating a small plot of land in which they are constantly surrounded by nature (FREIRE, 2000, p. 175). This creates in this class what he calls a condition of "semi-intransitive consciousness" in which one cannot "apprehend problems situated outside their sphere biological necessity" and largely accept their condition as an unchangeable given aking to natural law. This is a class largely guided by tradition, driven by biological needs, and susceptible to what he calls "magical explanations because they cannot apprehend true causality” (FREIRE, 1974, p. 14). 
Second, Freire's reforms must be situated as a response to the challenge of "rural extension", or the effort by the state to transfer modern techniques and knowledge to these rural peasants in order to alter traditional practices and improve productivity.That is to say, the reason this peasant class became a matter of concern to the state in the mid- $20^{\text {th }}$ century was that reforming their practices was necessary to the development of a sustainable and profitable economy. Understood as a sustained effort at educating illiterate peasants, learning about their language and practices, transforming them into citizens, and helping them take control of their lives and their environment, Freire wholly supported this endeavor. His own work teaching literacy was an essential component to this campaign, in fact, because peasants had to be literate in order to be able to understand and apply modern techniques. The problem was not with the aim of education but with the method of "extension." As he stated:

I do not... wish to deny the agronomist working in this field the right to be an educator-educatee, with the educatee-educator peasants. Precisely because I am convinced that it is their duty to educate and to be educated, I cannot accept that their work be labeled by a concept which negates it (FREIRE, 1974, p. 85).

This is because, unlike in education, "there is in the concept of extension an unquestionably mechanist connotation, inasmuch as the term implies an action of taking, transferring, of handing over, and of depositing something in someone” (FREIRE, 1974, p. 88). In other words, "extension" carried with it all of the negative connotations that Plato had also given "rhetoric", namely by being a method by which the dominant controlled and manipulated the dominated. It thus transformed the project of communication into one of propaganda.

One way to understand Freire's pedagogical mission is to see it as an endeavor to emancipate peasants from their state of semi-intransitive consciousness without replacing it with a new form of oppression through 
propaganda. He makes the connection between extension and propaganda explicit in his writings leading up to Pedagogy of the oppressed, compiled under the title Education for critical consciousness. There, he reacts to a quotation from a member of the Brazilian Ministry of Agriculture which read as follows: "One of the most difficult tasks is to persuade the rural masses to accept our propaganda and put these possibilities into practice. This task is precisely that of the extension agent, whose duty is to maintain a permanent contact with the rural masses" (FREIRE, 1974, p. 86, emphasis by Freire). For Freire, these words capture all of the negative connotations that connect persuasion that extension: "In the text quoted, 'persuade' and 'propaganda' are terms which seem to share a basic connotation which semantically meet in the term 'extension'”. The reason is clear: "to persuade implies, fundamentally, a Subject who persuades, in some form or other, and an object on which the act of persuading is exercised. In this case the Subject is the extension agent - the object the peasants. They are the objects of a persuasion which will render them all the more susceptible to propaganda" (FREIRE, 1974, p. 86). In his introduction to Freire's work, Denis Goulet (1974) makes explicit the consequences of this position:

The mark of a successful educator is not skill of persuasion - which is but an insidious form of propaganda - but the ability to dialogue with educatees in emotional reciprocity. And rural extension fails as communication because it violates the dialectic of reciprocity; indeed no change agent or technical expert has the right to impose personal options on others (GOULET apud FREIRE, 1974, p. xii).

Persuasion is thus the application of persuasive strategies to manipulate a passive audience once the ideology of "extension” has properly transformed them into objects to be manipulated.

In practice, then, the application of "extension" within a context of inequality amounts to what Freire calls "cultural invasion" in which all acts of communication are in effect expressions of authority of the invader 
over the invaded. On the receiving end there is the invaded Object that is empty and passive. On the active and there is the invading Subject who "seeks to penetrate another cultural-historical situation and impose his system of values on its members". The result is a communicative relationship that is fundamentally anti-dialogic in nature:

the invader acts, the invaded are under the illusion that they are acting through the action of the other; the invader has his say; the invaded, who are forbidden this, listen to what the invader says. The invader thinks, at most, about the invaded, never with them; the latter have their thinking done for them by the former (FREIRE, 1974, p. 100).

Yet in the context of extension, it is also important to recognize that this cultural invasion is always done on behalf of the invaded. There is always an aspect of "messianism" to this cultural invasion (in the context of Brazil, a specifically "technical messianism” which "proposes modernization of existing structures in opposition to traditionalism") that confers on the invader "the role of and infallible savior" (FREIRE, 1974, p. 112). The result is the replacement of the use of physical force with the implementation of a messianic propaganda which domesticates rather than liberates. In this context, "propaganda, slogans, myths are instruments employed by the invader to achieve his objectives: to persuade those invaded that they must be the objects of his action, that they must be docile prisoners of his conquest” (FREIRE, 1974, p. 101). Propaganda thus makes use (as all propaganda does) of the mass media not only in order to disseminate its slogans and communiqués to the masses but also to legitimize the practices of rural extension agents in the form of education.

This basic understanding of persuasion - that is, the strategic manipulation of other human beings as if they were objects to be "filled up" or "moved around" - then creates the foundation for Freire's famous critique of the "banking" concept of education. In effect, this critique 
is simply a restatement of his critique of persuasion, only without the emphasis on tactical adaptation. Instead, the focus falls on the reliance on "narrative." The outstanding characteristic of narrative education, he writes, is "the sonority of words, not their transforming power" (FREIRE, 2000, p. 71). Thus, "narration (with the teacher as narrator) leads to students to memorize mechanically the narrated content. Worse yet, it turns them into 'containers,' into 'receptacles' to be 'filled' by the teacher". Using the same terminology used to critique extension, he says that in narrative education, "instead of communicating, the teacher issues communiqués and makes deposits which the students patiently receive, memorize, and repeat” (FREIRE, 2000, p. 72). The messianic impulse, too, is the same, as the teacher uses "banking models of domination (propaganda, slogans - deposits) in the name of liberation" (FREIRE, 2000, p. 79). But this is really to utilize the tools of persuasion in the classroom, differing from mass mediated propaganda only by the effort to cloak it in a less threatening narrative form delivered by the benign voice of a teacher.

Freire's conception of dialogue thus can be understood as being developed as a corrective to rhetoric in every way. The definition he gives of dialogue in Pedagogy of the oppressed makes the dichotomy explicit: "since dialogue is the encounter in which the united reflection and action of the dialoguers are addressed to the world which is to be transformed and humanized, this dialogue cannot be reduced to the act of one person's 'depositing' ideas in another, nor can it become a simple exchange of ideas to be 'consumed' by the discussants" (FREIRE, 2000, p. 89). This latter conception, as we have already seen, is what Freire associate with the act of persuasion - an act guided by the negative virtues of contempt, arrogance, and cynicism that treats the other as a mere object. In contradistinction, dialogue is founded on the opposite virtues: "founding itself upon love, humility, and faith, dialogue becomes a horizontal relationship of which mutual trust between the dialoguers is the logical consequence” (FREIRE, 
2000, p. 91). Replacing the vertical authoritarian relationship of persuasion with the horizontal egalitarian relationship of dialogue, dialogue represents "the encounter between men, mediated by the world, in order to name the world" (FREIRE, 2000, p. 88). These words are thus not developed by one party and imposed upon the other, making them false, meaningless, and oppressive. Rather, the words used to name the world growth of the lived experience of the parties in dialogue are used, in turn, to alter their experience of the world through action. Consequently, "there is no true word that is not at the same time a praxis. Thus, to speak a true word is to transform the world" (FREIRE, 2000, p. 87). Whereas persuasion imposes merely artificial and surface changes on the world, covering it with a veneer of falseness, dialogue penetrates into the actual life of a person and transforms his or her world through the word.

Freire's conception of dialogue has immediate significance for pedagogical method and attitudes. At its most philosophical level, dialogue requires a rejection of a worldview of Being - that is, in which everything is fixed and completed - and an embrace of a worldview which "affirms men and women as beings in the process of becoming - as unfinished, uncompleted beings in and with a likewise unfinished reality" (FREIRE, 2000, p. 84). The opposite type of individual represents a commitment to Being and is often referred to as a "neoliberal" by Freire, meaning a person committed to the ideology of "modernizing discourse" largely aligned with corporate interests who, "speaking about the present moment in history, tries to convince us that life is just like this: the most capable organize the world, they produce; the least capable, survive” (FREIRE, 2005, p. 104). This world is presented simply as "fact" - something to be persuaded is unalterable. Or, more deceptively, these individuals may even pose as liberators, as either reactionaries and revolutionaries who believe that the future is either a repetition of the past or the guarantee of an inevitable future. For Freire, however, 
the idea of the inexorability of a history that will necessarily come in a predetermined manner constitutes what I call "liberation fatalism" or "fatalistic liberation" - a liberation to come as a kind of gift or donation of history: the liberation that will come because it has been said that it will come (FREIRE, 1998b, p. 91).

But pedagogy based on this notion of history simply reverts to a traditional model of persuasion tasked with domesticating the present on the basis of some known future; it has nothing to do with the kind of dialogue that is willing to call all things into question knowing they can be changed in a world that is in constant becoming.

On the level of specific practice, this commitment to Becoming entails, for Freire, an equal commitment to what he calls "problem-posing” education which looks at subject matter not as something to deposit in the mind but as something to investigate and question. Consequently, “'problem - posing' education, responding to the essence of consciousness - intentionality - rejects communiqués and embodies communication” (FREIRE, 1998b, p. 79). That is to say, it rejects the narrative education that simply disseminates a fixed discourse or subject matter and embraces a dialogic method in which the language and life experience of the students become the substance of investigation by being turned into a problem. In his method of teaching literacy, for instance, Freire recommends that teams of educators locate what he calls the best "generative words" to study in the classroom, selecting "only the words most weighted with existential meaning (and thus the greatest emotional content), but also typical things, as well as words and expressions linked to the experience of the groups in which the researcher participates" (FREIRE, 1974, p. 46). These words are then "codified," meaning visually represented in the context of the life experience of the people so that they can be used as a topic of discussion and co-investigation. The task of dialogical teachers "working on the thematic universe revealed by 
their investigation is to 're-present' that universe to the people from whom she or he first received it-and 're-present' it not as a lecture, but as a problem” (FREIRE, 2000, p. 109). To accept a worldview of becoming thus requires one to adopt problem posing education in the context of dialogue as a method in order to make good on the promise to cooperatively transform the world.

Third, the primary aim of dialogue is not to transmit subject matter from one place to another, which would be the goal of a persuasive communiqué; it is to produce what he calls conscientização (translated in English "conscientization") which "represents the development of the awakening of critical consciousness" (FREIRE, 1974, p. 15). In other words, conscientization is not a specific set of beliefs or body of subject matter; it is a transitive state, movement from a less to a more expansive and permeable consciousness that is brought about through dialogue. As Freire explains in Education for critical consciousness:

The critically transitive consciousness is characterized by depth in the interpretation of problems; by the substitution of causal principles for magical explanations; by the testing of one's "findings" and by openness to revision; by the attempt to avoid distortion when perceiving problems and to avoid preconceived notions when analyzing them; by refusing to transfer responsibility; by rejecting passive positions; by soundness of argumentation; by the practice of dialogue rather than polemics; by receptivity to the new for reasons beyond mere novelty and by the good sense not to reject the old just because it is old - by accepting what is valid in both old and new (FREIRE, 1974, p. 15).

This kind of consciousness is produced through dialogue when members of an oppressed class perceive what Freire calls "limit-situations", or the awareness of the obstacles and constraints which limit their personal and social lives, and decide to engage in "limit-acts" which are "directed at negating and overcoming, rather than passively accepting, 'the given'”. It is through dialogue that the oppressed de- 
veloped a critical consciousness of these limit situations, and "once perceived by individuals as fetters, as obstacles to their liberation, the situation stands out in relief from the background, revealing their true nature as concrete historical dimensions of a given reality" (FREIRE, 2000, p. 99). Conscientization in this way only becomes truly transitive when it then engages in some praxis, some action which is meant to alter these worlds in the spirit of becoming that aspires to a new and yet unactualized possibility.

Lastly, dialogue is ultimately preferable to persuasion because for Freire is only through dialogue that a semi-intransitive consciousness can produce a fully critically transitive consciousness. Rhetorical persuasion, whether in the form of the mass media or rural extension, tends to produce either naïve transitivity or, worse still, a fanaticized consciousness. Naïve transitivity, he writes, is "is characterized by an over-simplification of problems; by a nostalgia for the past; by underestimation of the common man; by a strong tendency to gregariousness; by a lack of interest in investigation, accompanied by an accentuated taste for fanciful explanations; by fragility of argument; by a strongly emotional style; by the practice of polemics rather than dialogue; by magical explanations" (FREIRE, 1974, p. 14). This is the state of a person dissatisfied with their present state and yet unable to develop a critical perspective of their own, seeking instead the satisfaction that comes from easily consumable polemics, emotional harangues, or fantastic explanations. A fanaticized consciousness is then what occurs when someone was naïve transitivity embraces one specific ideology and throws himself into a mass whereby they "followed general formulas and prescriptions as if by their own choice" (FREIRE, 1974, p. 16). This is the state of a person who no longer is capable of dialogue but only monologue, repeating the communiqués sanctioned by some ideology, whether reactionary or revolutionary. Only dialogue, in Freire's model, can avoid these pitfalls and make genuine becoming possible. 


\section{The rhetoric of the teacher}

Although this binary between dialogue and persuasion serves an important rhetorical function in Freire in the context of his situation namely by simultaneously highlighting the oppressive character of the "extension" policies of the state while praising the inherently emancipatory quality of his own pedagogy - it can be sustained neither from a conceptual nor methodological standpoint. Anthony Petruzzi (2001, p. 250), for instance, argues that Freire's entire pedagogical process rests on one of the most foundational of rhetorical concepts, that of kairos, which in classical rhetorical theory refers to that intuitive grasp of the "right moment" that a word should be spoken in order to move people to thought and action. According to Petruzzi, "kairos creates the possibility of new action through its power to disrupt the transparent and antecedent limits, the statis, of each individual's existential situation”. Rhetorical persuasion cannot occur, in other words, when an audience is in the grip of quotidian consciousness that refuses consideration of the new or different; it is only possible in a moment of Kairos, or that "critical moment [that] emerges from the rupture when discourse discloses or makes being known” (PETRUZZI, 2001, p. 349). From this perspective, then, Freire's "critical consciousness is rhetorical because it depends on a kairotic moment or a qualitative and discursive moment of understanding that leads to decisive actions that reimagine and re-structure that which was previously unthought” (PETRUZZI, 2001, p. 350). Far from being the opposite of persuasion, critical transitive consciousness is in classical rhetorical theory both its precondition and its desired outcome.

As soon as one talks about rhetoric from this kind of kairotic perspective, the easy Platonic dualisms between rhetoric and dialogue fall apart. Freire's critique of rhetoric and persuasion, as we have seen, is based on a somewhat facile notion that persuasion involves treating the other as a completely passive Object to be manipulated through language into performing some task or adhering to some belief predetermined 
by the persuading Subject. But as Kenneth Burke (1969, p. 21) has argued, rhetoric as it is actually practiced never treats its audience as a merely empty vessel. Genuine persuasion is always an act of what he calls "identification," or the creation between two or more people of "common sensations, concepts, images, ideas, [and] attitudes that make them consubstantial”. According to Burke, "identification ranges from the politician who, addressing an audience of farmers, says, 'I was a farm boy myself,' through the mysteries of social status, to the mystic's devout identification with the source of all being” (BURKE, 1969, p. xiv). What Burke means to stress, in other words, is that persuasion should not be understood as one party merely imposing itself on another, a conception which denies the agency of audiences; it is rather best understood as the attempt by one party to find common ground with the other by identifying the shared "substances" they have in common, whether those substances are emotions, nationalities, labor practices, personal ambitions, religious commitments, languages, or any number of interests, objects, values, or aims. Kairos in this model thus simply represent those moments in which our identifications are open to change, when we call into question the "substance" of our being and become willing to cast off and take on new properties. Rhetoric from a kairotic perspective is thus responsible both for creating those situations through symbolic action and for proposing new possibilities for different identifications.

In Freire, this understanding of rhetoric is perhaps most explicit in his commitment to prophetic witness as a component of his pedagogy a form of discourse which is clearly connected with the rhetorical spirit of kairos. Prophecy, he writes, "affirms women and men as beings who transcend themselves, who forward and look ahead, for whom immobility represents a fatal threat, for whom looking at the past must only be a means of understanding more clearly what and who they are so they can more wisely build the future" (FREIRE, 2000, p. 84). But the one who would deliver this sort of prophecy must also, in his words, be a witness - that is to say one who does not speak at people from a distance 
but realizes that "the struggle for liberation is a common task" (FREIRE, 2000, p. 176). According to Tyson Lewis (2012, p. 65), the witness is "simultaneously one who records the experiences of others as well as one who actively intervenes in the very processes which silence, marginalize, and exploit the oppressed through an aesthetic reconstruction of what can be heard, seen, and experienced". To be a prophetic witness is thus a fundamentally rhetorical act; it involves not only understanding and experiencing the being of one's audience but the capacity to aesthetically represent and reconstruct those experiences through discourse which disrupts their quotidian consciousness so that they can reconstruct their identities - that is, propose new consubstantialities - commensurate with a growth toward a utopian future.

The challenge with Freire, however, has been to find a way to translate this kind of emancipatory rhetoric into a discourse more appropriate for a quotidian classroom. Indeed, what is often lost when reading Freire is the fact that despite his call for prophetic witness, most of his actual classroom practice involved the teaching of basic phonetic sounds to illiterate adults so that they could begin to read and write rudimentary words and sentences. His use of "generative words" and visual "codifications" were methods used to engage his audience at a level that spoke to their own lifeworlds and experiences, but ultimately they were still directed toward the acquisition of literacy. Furthermore, at a higher level, Freire was as concerned as rural extension agents with confronting and transforming the magical thinking of many peasants. For instance, he gives him an example of a folk belief from a peasant from Northeast Brazil who believes, "with absolute conviction, that he cures the infected wounds of his animals by praying over the tracks they lead in the mud". He makes clear that his call for dialogue does not at all entail legitimizing these sorts of beliefs and practices, noting that he in fact rejects "all that it contains in the way of 'theory' for pseudoscience, concludes a whole area of 'technical knowledge'”. His critique of methods of extension agents thus had less to do with their aim - which was to reform practices - than with 
their method that showed no understanding of the larger social context in which those practices were embedded. Dialogue thus developed on the basis of the principle that "to understand the signification of the linguistic signs used by peasant implies that we comprehend the context in which the conviction expressed by those signs was engendered” (FREIRE, 1974, p. 126). To simply deliver a communiqué that outlined a new method of farming, without understanding how those linguistic signs would be interpreted within the context of centuries' old magical thinking, is simply to speak into the air. Freire did not reject agricultural reform or the teaching of “content." He simply wanted that teaching grounded in the principle of rhetorical adaptation that to speak effectively is to speak the language of one's audience. For all that Freire's writing celebrating the emancipatory nature of the rhetoric of prophetic witness, most of this witnessing occurs in the context of a somewhat traditional classroom.

This aspect of Freire is crucial to point out if Freire's ideals of dialogical education are, in fact, to be put into effective practice by others. In other words, the reason is important to recognize the centrality of rhetorical methods and practices to Freire's pedagogy is that his notion of dialogue, understood as something that is the opposite of rhetoric and persuasion, is not itself self-sufficient to perform the functions he demands of it. From the very beginning of his work, he was consistently confronted with the complaint that dialogue, while valuable for discussing the society and culture of peasant communities, was inappropriate for teaching technical affairs and required too much time and intimacy. In Freire's words, agronomist educators would complain that dialogue, "in spite of the results it may produce, is at odds with the urgent need of the country to stimulate production" or would ask "how can we dialogue about technical affairs? How can we dialogue with peasants about a technical method they are not familiar with?” (FREIRE, 1974, p. 103). Freire's response to these criticisms has largely been to restate his critique of the banking model of education and insist that dialogue should not be considered wasted time because "it presents problems and criticizes, and 
in criticizing, gives human beings their place within their own reality as the true transforming Subjects of reality” (FREIRE, 1974, p. 107). Yet this position, while undoubtedly true, does not itself provide a method for teaching technical affairs.

It is my argument that rhetoric provides the necessary corrective to the insufficiency of dialogue - narrowly conceived - to fulfill not only the aims of giving human beings their place within their own reality but also acquiring the knowledge and skills necessary to acquire power within that reality. Moreover, in his later work, Freire (1988b, p. 108) has more recognized this necessity by creating a space for what he calls the "expository lesson," which is simply the traditional lecture performed with a rhetorical sensibility. As he makes clear with respect to his critiques of banking education,

the real evil is not in the expository lesson - in the explanation given by the teacher. This is not what I criticized as a kind of 'banking.' I have criticized and I continue to criticize, that type of educator-educand relationship in which the educator regards himself or herself as the educands' sole educator - in which the educator violates, or refuses to accept, the fundamental condition of the act of knowing, which is its dialogical relation (FREIRE, 1988b, p. 108).

These are fundamentally vertical classrooms which attempt, through monologue, "pure transferrals of the teacher's accumulated knowledge to the students". However, he says there are two forms of expository teaching which conform to the values of dialogue. First, there are cases in which "the teacher makes a little presentation of the subject and then the group of students joins with the teacher in an analysis precisely of that presentation," in which students "question themselves and question the teacher, and thereby share in plumbing the depths of, developing, the initial exposition". Second, he acknowledges the value of "that very serious teacher who, in conducting a course, adopts a relationship of the subject, with the content, of which she or he is treating, that is one 
of profound, affectionate, almost loving respect”. In these cases, the teacher is actually "bearing witness" by revealing his or her passion for the subject, and the necessity for genuine education comes from the fact that "the educands must have, or create and develop, the critical ability to accompany the teacher's movement in his or her attempt to approach the topic under discussion” (FREIRE, 1988b, p. 109). For experienced teachers, these methods are hardly new or revolutionary; they are the methods of a teacher who, through years of classroom experience, has developed a rhetorical presence in the classroom and whose words display a love of wisdom and a desire to stimulate that same love in the students.

For Freire, then, there are three essential rhetorical principles to that must be adhered to in adapting expository lessons within a dialogical classroom. The first is to understand the attitudes and the cultural context of one's audience. One of his consistent critiques of banking education is its inability to understand that any knowledge, however "true" at a technical level, only becomes knowledge when it is embedded in the lifeworld of the one being taught. Consequently, the teacher must begin as something of an ethnologist. That is to say, one ought not "to teach what one knows without, first, knowing what those one is about to teach know and on what level they know it; and second, without respecting this knowledge" (FREIRE, 1998b, p. 120). For instance, in the Brazilian context, he notes that one cannot reform agricultural practices without first getting to know "how rural popular groups, indigenous or not, know - how they organize their agronomic knowledge or science, for example, or their medicine, to which and they have developed a broadly systematized taxonomy of plants, herbs, trees, spices, roots” (FREIRE, 1988b, p. 124). As he makes clear, however, this local knowledge need not be simply reaffirmed, which would leave students exactly in the same place where they began. Consistent with principles of rhetorical persuasion, to effectively introduce new beliefs or attitudes to an audience requires integrating them within pre-existing beliefs and attitudes so that they form a consistent whole. For example, he notes that peasant "attitudes toward 
erosion, reforestation, seedtime or harvest...have a relation to peasant attitudes to religion, to the cult of the dead, to the illness of animals, etc. All these aspects are contained within a cultural totality” (FREIRE, 1988b, p. 95). Any effective reform practices must therefore take prior account of the attitudes in order to produce changes that can be adapted - however rapidly or gradually - to this cultural totality.

Second, teachers when delivering expository lectures or producing educational writings should attend to the principles of rhetorical style and delivery that speaks, when possible, in the language of one's audience rather than in the technical jargon of a discipline. As he observes, "a writer commits no sin against scholarship by refusing to wound the ear and good taste of the person reading or hearing his or her discourse, and may not, in so refusing, simplistically be accused of being 'rhetorical' or of succumbing to the 'fascination of a linguistic elegance as an end in itself'” (FREIRE, 1998b, p. 62). This does not mean, however, simply watering down one's content or addressing an audience as if they were children. It is, on the one hand, to recognize that "writers using scientific, academic language cannot become simplistic even though they must attempt to become more accessible, clearer, simpler, less closed, and less difficult” (FREIRE, 2005, p. 40). But perhaps more importantly, on the other hand, is to recognize the value added that comes from integrating aesthetics and beauty into one's language that expresses passion for knowledge and care for the other. He writes that "language's esthetic moment, it has always seemed to me, ought to be pursued by all of us, including rigorous scholars” (FREIRE, 1998b, p. 61). In this goes beyond mere stylistic adaptation. That is to say, Freire (FREIRE, 1998b, p. 100) believes it is important "to show students that there is beauty in the ethical struggle. Ethics and aesthetics are intimately tied together". Rhetorically, this means realizing that the teaching of knowledge is also an ethical project that involves transformation of the self and the culture to which that self belongs; part of the rhetoric 
of teaching is to balance the need to inspire "understanding" with the development of the language that, in classical terminology, can also arouse passions and move the will.

Third, any expository lesson, from a rhetorical perspective, must not be content with mere verbal instruction but must endeavor to connect theory with practice so that students can perceive how this knowledge can be used to transform some situation, whether local, national, or global. This is the meaning of praxis for Freire (2000, p. 51), which is "reflection and action upon the world in order to transform it”. The meaning of dialogue in education, for Freire, refers not only to the dialogue between teacher and student but also referred to the dialogue between the individual and the environment mediated by new forms of knowledge, meaning that

dialogue in any situation (whether it involves scientific and technical knowledge, or experiential knowledge) demands the problematic confrontation of that very knowledge in its unquestionable relationship with the concrete reality which it is engendered, and on which acts, in order to better understand, explain, and transform that reality (FREIRE, 1974, p. 108).

Rhetoric within this model is not simply to persuade people to accept the truth of the teacher and dutifully perform experiments on nature; it is to inspire in students what he calls "epistemological curiosity" that makes them feel active agents in the discovery and transformation of their environment. This is curiosity "as restless questioning, as movement toward the revelation of something hidden, as a question verbalized or not, as search for clarity, as a moment of attention, suggestion, and vigilance” (FREIRE, 1998a, p. 37-8). Rhetoric in this dialogical method is a calling to praxis, as a pointing to possibilities of action and a bolstering of the confidence of the students as individuals with the right and the power to make experimental interventions into their world and to reflect upon those changes both cognitively and ethically. 
From these examples, we can see how the rhetorical development of teachers is a crucial component to fulfilling the aims of Freire's dialogical pedagogy. By no means does this mean giving into the messianic temptations of neoliberal discourse that places solely upon the teacher the heroic burden of persuading the masses to cast off their ignorance and replace tradition en mass with a new ideology. Rather, it means taking seriously the rhetorical project of adapting one's language to one's audience, to speaking in a way that both teachers and inspires, and which points to the places in which knowledge can be translated into practice and then reflected upon ethically by a community. Furthermore, dialogue remains a crucial component of any classroom, no matter how technical the subject matter. The expository lecture does not dominate the language of the students but rather carves a space in which new knowledge, new words, new perspectives, and new artifacts can be presented as subjects of dialogue. But this, in turn, requires a dialogical consciousness that recognizes the multiplicity of interpretations for any subject matter - that “a poem, a song, a sculpture, a painting, a book, a piece of music, a fact or deed, an occurrence, never have just one reason to explain them," but are always "found wrapped in thick webs, tapestries, frameworks, and touched by manifold whys" (FREIRE, 1998b, p. 110). The responsibility of rhetoric in this classroom is not to provide all the answers but to persuade the students that it is worthwhile to ask questions, to consider new possibilities, and to ask why.

\section{The rhetoric of citizens}

If the methods of the expository teacher in Freire are reminiscent of those of Plato, the political aims of the dialogical educator are closer to that of the Greek Sophists. Whereas Plato was ultimately concerned with teaching the children of aristocrats to become philosopher kings, Sophists like Protagoras arose in a revolutionary context in which new democracies created space for a new kind of citizen whose power origi- 
nated not enforce but in logos. The mid- $5^{\text {th }}$ century BCE in Greece was thus what John Poulakos describes as a time when

the aristocracy of the nobility was yielding to a democracy of citizens; the aristocracy of the myths was losing its authority to a democracy of public arguments; the aristocracy of the oracles was receding before a democracy of human laws; and the aristocracy of poetry was relinquishing its glory to a democracy of prosaic discourses (POULAKOS, 1995, p. 14).

It was the Sophists who first articulated a comprehensive humanistic worldview which undergirded democratic practice and developed and taught the arts of logos - that is, of persuasion, speech, and reason - that would become the specialized discipline we now know as "rhetoric." The Sophists were thus the "first to infuse rhetoric with life", thus demonstrating "to the rest of the world that rhetoric is an integral part of the social life of all civilized people” (POULAKOS, 1983, p. 35). They accomplished these tasks not by any tricks of persuasion but simply by making clear "close connection between well-crafted logoi and the acquisition of power” (POULAKOS, 2004, p. 78). To recognize the importance of the Sophists to Freire is thus to recognize that his education is about more than just expressing love. As Stanley Aronowitz has forcefully argued, a student who emerges from a dialogical pressroom ready to question, act, ask questions, and be recognized as an agent of change, is a learner who "is ready to demand power, which, after all, is the object of a pedagogy of freedom" (FREIRE,1998a, p. 19). But this is to acknowledge the sophistical element that is so central to Freire's project.

If the previous section encouraged the development of rhetorical skills on the part of the teacher, this section shows how achieving Freire's ethical aim also requires the cultivation of rhetorical skills and attitudes in the students consistent with models of democratic citizenship. In this he is explicitly conscious of the need for rhetorical intervention: "at the heart of the experience of coherently democratic authority is a basic, 
almost obsessive dream: to persuade or convince freedom of its vocation to autonomy as it travels the road to self-construction, using materials from within and without, but elaborated over and over again" (FREIRE, 1998a, p. 87). To recognize the relevance of the Sophists to this aim is simply to recognize that the road to self-construction also requires the ability to express one's agency through rhetoric capable of challenging and directing power. Citizenship is thus not simply a right that one simply inherits; it is also an art that one wields. As Freire explains, "citizenship is not obtained by chance: it is a construction that, never finished, demands we fight for it. It demands commitment, political clarity, coherence, decision. For this reason a democratic education cannot be realized apart from education of and for citizenship” (FREIRE, 2005, p. 161). But in a modern, political environment in which power and logos are closely aligned, this also means that a democratic education cannot be realized apart from an education in rhetoric.

Perhaps the most important aspect of this rhetorical training and the one that flows directly out of his critique of persuasion - is to encourage in students the development of their own language that speaks to their cultural heritage and expresses their unique power and possibility. The problem with messianic forms of education, that is to say, is that no matter the virtue of theirs stated ideals, they ultimately deny students their own language and replace it with a foreign terminology, which in many ways is a colonial enterprise. Freire (1998b, p. 31) argues that one of the most important "tasks of democratic popular education, of a pedagogy of hope" is "that of enabling the popular classes to develop their language: not the authoritarian, sectarian gobbledygook of 'educators,' but their own language - which, emerging from and returning upon their reality, sketches out the conjectures, the designs, the anticipations of their new world. Here is one of the central questions of popular education - that of language as the route to the invention of citizenship". But this question has always been a component of genuine rhetorical 
training of citizens since the time of the Sophists in recognizing the fact that logos can only be a vehicle for one's own power when that logos is one's own and not that of another.

The method of rhetorical education most consistent with the spirit of Freire's dialogism is the sophistical practice of dissoilogoi. First advanced by the Sophist Protagoras, the concept of dissoilogoi operates on the principle that, in Edward Schiappa's words, "there are two logoi in opposition about every 'thing'”, in which logoi refers to arguments, positions, perspectives, stories, or accounts (SCHIAPPA, 2003, p. 89).Practically speaking, according to John Poulakos (1995, p. 58), this concept means "that in order to understand an issue, one must be prepared to listen to at least two contrary sides, and in order to decide how to act, one must espouse one of the two sides or come up with a third". In other words, dissoilogoi is not simply a statement of the obvious fact that one can argue both sides of an issue, as when one might play a "devil's advocate" to a known truth for the sake of testing it; it is actually a stronger claim that challenges the idea that there is only one valid position. According to Susan Jarratt (1991, p. 49), the Sophists "understood dissoilogoi to be a means of discovering $a$ truth rather than the expression of a distance from a separate, single Truth within phenomena”. Rhetorical training from a sophistical perspective thus meant being able to see multiple sides of an issue and argue them as if they were equally valid in order to determine one's own unique judgment on a case that rejects simplistic dualisms and black-and-white thinking.

The importance of rhetorical training through dissoilogoi has already been identified in passing in Freire when defining his conception of critically transitive consciousness. There, he identified such consciousness as being characterized by "rejecting passive positions; by soundness of argumentation; by the practice of dialogue rather than polemics," all of which he believed is "characteristic of authentically democratic regimes and corresponds to highly permeable, interro- 
gative, restless and dialogical forms of life” (FREIRE, 1974, p. 15). In his later work, the rhetorical significance of this commitment to producing a critically transitive consciousness becomes explicit. In contradistinction to hierarchical classrooms dominated only by one a single logos, Freire argues that

to defend a thesis, a position, a preference, with earnestness, defend it rigorously, but passionately, as well, and at the same time to stimulate the contrary discourse, and respect the right to utter that discourse, is the best way to teach, first, the right to have our own ideas, even our duty to "quarrel" for them, for our dreams - and not only to learn the syntax of the verb, haver; and second, mutual respect (FREIRE, 1998b, p. 67).

There is no better summary of the spirit of rhetorical pedagogy grounded in dissoilogoi, which is wholly consistent with training in democratic citizenship in which an individual is taught to express their own language with power at the same time that they understand, respect, and incorporate the positions of others so that genuine cooperation might be possible within a pluralistic society.

\section{Conclusion}

A model for the kind of citizen produced by sophistical education in dissoilogoi was, in fact, on display when Freire gave the example of his encounter with the young father who confronted him after his lecture. Here was a man who understood the perspective of Freire and yet respectfully challenged that perspective with his own, who spoke directly from his own experience with his own language with passion and force, and who sought to make some public intervention through his language into the political circumstances that confronted his family and his community. At the time Freire wrote of his past experience, he noted that it still spoke to him: 
The discourse of that faraway night is still before me, as if it had been a written text, an essay that I constantly had to review. Indeed, it was the culmination of the learning process I had undertaken long ago - that of the progressive educator: even when one must speak to the people, one must convert the "to" to a "with" the people. And this implies respect for the "knowledge of living experience" of which I only speak, on the basis of which it is possible to go beyond it (FREIRE, 1998b, p. 20).

That is to say, Freire had absorbed both the Platonic and the sophistical lessons of rhetoric - that he had to know the souls of the audience whom he was trying to inspire, and that the end result of that pedagogy was the creation of a citizen capable of speaking with power.

Incorporating rhetorical methods and attitudes into Freire's pedagogy is thus not to insert foreign elements into his system; it is rather to recognize those practices already ongoing and to make them explicit and thereby more effective. Jarratt, in fact, has already recognized both Platonic and sophistical elements in Freire. On the one hand, she notes that "Freire sounds quite Socratic at moments, claiming to act as a midwife and the birth of consciousness, desiring to overthrow doxa in favor of logos, and openly declaring a loving attitude toward his students" (JARRATT, 1991, p.109). On the other hand, she notes resonances between Freire and the "sophistic practice of anti-logic, [whereby] contradictions emerging out of cultural discourses are brought to a level of consciousness so that they can come under analysis” (JARRATT, 1991, p. 110). It is my argument that both of these tendencies in Freire must be acknowledged and cultivated in order that his emancipatory aims to be fulfilled. Doing so would not only provide teachers more explicit resources by which to make knowledge meaningful to the "souls" of their students, but would provide a method whereby even the most technical knowledge is made a subject of debate and argumentation so that students develop the attitudes of criticism and skills in advocacy that are necessary to defend themselves against invasion and pursue their own interests with love. 
Freire's work continues to speak to those dissatisfied with the promises of neoliberal ideology and the practices of its messianic educators. Bridging the divide between dialogue and rhetoric in Freire is now the necessary step in order to allow his work to speak with greater power.

\section{References}

BROWN, Stephen. The radical pedagogies of Socrates and Freire: ancient rhetoric/radical praxis. New York: Routledge, 2011.

BURKE, Kenneth. A rhetoric of motives. Berkeley: University of California, 1969.

FREIRE, Paulo. Education for critical consciousness. London: Bloomsbury, 1974.

. Pedagogy of freedom: ethics, democracy, and civic courage. New York: Roman and Littlefield, 1998a.

. Pedagogy of hope: reliving Pedagogy of the oppressed. London: Bloomsbury, 1998b.

. Pedagogy of the oppressed. New York: Continuum, 2000.

. Teachers as cultural workers: letters to those who dare teach. Boulder, CO: Westview Press, 2005.

JARRATT, Susan C. Rereading the sophists: classical rhetoric refigured. Carbondale: Southern Illinois UP, 1991.

LEWIS, Tyson E. The aesthetics of education: theatre, curiosity, and politics in the work of Jacques Ranciere and Paulo Freire. London: Bloomsbury Publishing, 2012. Disponível em: <http://dx.doi. org/10.5406/jaesteduc.46.1.0027>. Acesso em: 18 maio 2015.

PETRUZZI, Anthony. Kairotic rhetoric in Freire's liberatory pedagogy. JAC, Amherst, v. 21, n. 2, p. 349-381, 2001. 
PLATO. Phaedrus. Trans. Alexander Nehamas and Paul Woodruff. In: COOPER, John M. (Ed.). Plato - complete Works. Indianapolis: Hackett Publishing, 1997.

POULAKOS, John. Toward a sophistic definition of rhetoric. Philosophy and Rhetoric, Columbia, n. 16, p. 35-48, 1983.

Sophistical rhetoric in classical Greece. Columbia: University of South Carolina, 1995.

Rhetoric and civic education: from the Sophists to Isocrates. In: POULAKOS, Takis; DEPEW, David (Ed.). Isocrates and civic education. Austin: University of Texas, 2004.p. 69-83.

SCHIAPPA, Edward. Protagoras and logos: a study in Greek philosophy and rhetoric. Columbia: University of South Carolina, 2003.

WEAVER, Richard. The ethics of rhetoric. Davis, CA: Hermagoras, 1985.

Data de registro: 31/10/2015

Data de aceite: 23/03/2016 